Obrazovanje odraslih/Adult Education, ISSN 1512-8784, Broj I - 202 I., str. 79-92

UDK: 004.5:373.1

DOI: $10.53617 /$ issn2744-2047.2021.21.1.79

Pregledni članak/Rewiev paper

Primljeno/Received: 03. 05. $202 \mathrm{I}$.

Prihvaćeno/Accepted: 09. 06. 202 I.

Mirza Mahmutović

\title{
Škola u oblaku: \\ online platforme kao posrednici obrazovanja
}

Sažetak: U radu se problematiziraju procesi implementacije digitalnih platformi, osobite skupine mrežnih medija, u polju obrazovanja. Kritički se razmatraju učinci mehanizama platformi na dosadašnje koncepte učenja, posebno ideju obrazovanja kao općeg dobra. Posebna pažnja se poklanja implikacijama „pandemijske pedagogije“ uvjetovane pojavom bolesti COVID-19 na rekonfiguraciju dosadašnjih praksi i institucija obrazovanja. Rad upućuje na plodotvornost interdisciplinarnog dijaloga medijskih studija i sociologije obrazovanja u analizi dinamike i preobražaja suvremenih obrazovnih sistema.

Ključne riječi: platforme, digitalni mediji, obrazovanje, edtech industrija, COVID-19.

\footnotetext{
${ }^{1}$ Dr. sci. Mirza Mahmutović, vanredni profesor, Univerzitet u Tuzli, Filozofski fakultet. Adresa: dr. Tihomila Markovića 1, 75000 Tuzla, Bosna i Hercegovina. E-mail: mirza.mahmutovic@unitz.ba.
} 


\section{Platformizacija obrazovanja, cui bono?}

Brojne su studije mrežnih medija (npr. Helmond 2015; Van Dijck 2013; Gillespie 2010) skrenule pažnju na ekspanziju digitalnih platformi tokom posljednja dva desetljeća i važnost razmatranja implikacija ovih procesa na reorganizaciju društvenih interakcija i institucija, uključujući i polje obrazovanja.

U akademskom diskursu (Zuboff 2019; Yeung 2018; Bauman et al. 2014) posebna zabrinutost izražena je u pogledu odnosa moći, struktura dominacije i obrazaca nadzora koji su uspostavljeni unutar ovog „platformskog ekosistema“. Prema pojedinim autorima (Van Dijck, Poell i De Waal 2018; Galloway 2018; Gehl 2013), sporno je što infrastrukturu ekosistema, od koje suštinski zavisi funkcioniranje online prostora Sjeverne Amerike i Europe, kontrolira (i posjeduje) pet visokotehnoloških korporacija, Google-Alphabet, Facebook, Apple, Amazon i Microsoft, tzv. „velika petorka“.2 Van Dijck, Poell i De Waal (2018: 12) upućuju na niz proturječnosti koji karakterizira ovo socio-tehnološko okruženje. Korporativni slogani i retoričke figure tako prenaglašavaju, nerijetko $s$ utopijskim konotacijama, određene pretpostavljene potencijale platformi (egalitarnu narav, služenje interesima zajednice, neutralnost i agnosticizam kao vrijednosne orijentacije, lokalne učinke, promicanje tzv. pristupa „odozdo prema gore“ s ciljem „osnaživanja korisnika“, itd.). Istovremeno, s druge strane, strateški se previđaju njihova stvarna obilježja (hijerarhijsko ustrojstvo, korporativnokomercijalni interesi, promicanje neoliberalnih vrijednosti, globalni opseg djelovanja, netransparentnost mehanizama u pozadini rada servisa samim korisnicima, itd.).

Ovi autori prave razliku između dva tipa platformi. Infrastrukturne platforme obrazuju jezgro ekosistema, osnovu na kojoj se razvijaju svi ostali servisi. One djeluju kao svojevrsni „online vratari“, koji kontroliraju ključna čvorišta mreže posredstvom kojih se usmjeravaju, obrađuju i pohranjuju tokovi podataka. Većinu ključnih infrastrukturnih resursa, koje čine okosnicu zapadnog „platformskog ekosistema“, osigurava „velika petorka“. Uskraćivanje pristupa infrastrukturnim uslugama koje kontrolira ova skupina korporacija, praksa koju u javnom diskursu izražava sve učestaliji termin „deplatformizacija“, upućuje na

\footnotetext{
${ }^{2}$ U geopolitičkom smislu, jedina „protuteža“ okruženju koji kontrolira „velika petorka“ čini „kineski ekosistem“, u kojem isto tako dominira nekolicina velikih tvrtki, kao što su Alibaba, Baidu, JD.com, Tencent, pod snažnim utjecajem države.
} 
asimetrične odnose moći i mehanizme ovisnosti koji prevladavaju unutar ovog okruženja.

Drugi tip, sektorske platforme, ciljano su usmjerene na pružanje usluga za jedan specifični sektor, poput prijevoza, ugostiteljstva, zdravstva, a sve više i obrazovanja. Tipično se (samo)predstavljaju kao „poveznice“ koje spajaju „korisnike“ sa „pružateljima usluga“. Neke od najuspješnijih sektorskih platformi, kao što je Uber u sektoru urbanog transporta ili Coursera u oblasti obrazovanja, same većinom ne zapošljavaju radnike koji opslužuju sektor u kojem djeluju (u ovom slučaju, vozače odnosno nastavno osoblje), uglavnom ne posjeduju materijalne resurse neophodne za rad u sektoru (prijevozna sredstva, odnosno školske zgrade i nastavna pomagala), a nerijetko sami ni ne proizvode dobra niti nude usluge ključne za sektor (prijevoz, odnosno osmišljavanje kurseva). Sektorske platforme stoga zavise, s jedne strane, od skupa pojedinaca i organizacija koje pružaju usluge krajnjim korisnicima. $S$ druge strane, platforme omogućavaju i oblikuju odnose između obje skupine na određeni način, promovirajući u procesu posredovanja osobite vrijednosti. „Velika petorka“ snažno je prisutna, važno je naglasiti, i unutar okruženja sektorskih platformi, a integracija usluga oba tipa platformi čini ove korporacije vrlo utjecajnim akterima u globalnom online prostoru.

Ekspanzija platformi namijenjenih obrazovanju tokom posljednjeg desetljeća, samo razumijevanje obrazovanja kao jednog od poslovnih sektora visokotehnoloških tvrtki, potakla je interdisciplinarna proučavanja učinaka platformi na dosadašnje koncepte podučavanja i učenja (Williamson 2020; 2017; Selwyn Henderson i Chao 2016; Van Dijck i Poell 2015; Ashman et al. 2014; Koedinger, McLaughlin i Stamper 2014). Posebna pažnja, naročito u kontekstu europskih država, poklanja se društvenopolitičkim učincima implementacije digitalnih platformi u oblasti obrazovanja. Naime, uprkos razlikama u obrazovnim sistemima i politikama, europske države povezuje tradicija vrednovanja obrazovanja kao općeg dobra. Riječ je, u osnovi, o normativno pretpostavljenom odnosu između demokratskog uređenja i javno finansiranog sistema obrazovanja, čija se funkcija ne iscrpljuje u izobrazbi pojedinca (ovladavanje vještinama potrebnim za tržište rada), nego teži obrazovanju emancipiranog, samomislećeg, slobodnog čovjeka (Rupčić 2015). Bildung koncept klasični je simbol takve filozofije obrazovanja. Ideja obrazovanja kao općeg dobra sadrži tako određeni 
korpus normativno pretpostavljenih vrijednosti: obrazovanje kao pokretač društvenoekonomske jednakosti, priuštivost obrazovanja, kurikulumi usmjereni usvajanju znanja, a ne samo kompetencija, autonomija nastavnika, organizacija i status škola kao javnih ustanova, itd. Ključno je pitanje, u tom kontekstu, odnosa (ili tenzija) između vrijednosti koje pretpostavlja sistem javnog obrazovanja i novih koncepata učenja koje promoviraju edukacijske platforme.

Koncept personaliziranog učenja, na primjer, temelji se na praćenju rada učenika i učitelja u realnom vremenu, kontinuiranom prikupljanju podataka i evaluaciji performansi pomoću automatizirane analize podataka. Osim što primat daje usvajanju specifičnih vještina koje definira tržište rada, također pretpostavlja središnju ulogu nauke o podacima u pedagoškom procesu, uz nastavnike i obrazovne ustanove legitimizira autoritet tzv. data znanstvenika, algoritama i korporacija, a također preobražava granice između privatne i javne sfere (dom kao učionica, upotreba privatnih podataka, odsustvo sistema javne kontrole, itd.). Sektorske platforme orijentirane ka obrazovanju tako reorganiziraju procese učenja i podučavanja prema normama koje prevladavaju unutar ovog ekosistema, a na koje snažno utječu činioci kao što su korporativno vlasništvo, poslovni modeli zasnovani na privatiziranju, kodiranju i monetiziranju (online) ponašanja korisnika i algoritamsko ustrojstvo platformi.

U ovom radu zalažemo se za razvoj interdisciplinarnog okvira za kritičko sagledavanje dinamike restrukturiranja polja obrazovanja koju uvjetuju, iniciraju i usmjeravaju akteri „platformskog ekosistema“. Oslanjamo se na nalaze studija digitalnih medija i sociologije obrazovanja, s ciljem ispitivanja učinaka online platformi na dosadašnje koncepte učenja i podučavanja. Posebnu pažnju skrećemo na implikacije „pandemijske pedagogije“ (Williamson, Eynon i Potter 2020): u kojoj mjeri je kriza obrazovanja koju je uzrokovala pojava koronavirusa bila iskorištena kao prilika za osnaživanje pozicije visokotehnoloških korporacija i svojevrsni prototip za buduće oblike školovanja?! U konačnici, u funkciji obrazovanja alternativnog razumijevanja upotrebe digitalnih tehnologija $\mathrm{u}$ obrazovanju, u zaključku rada upućujemo na potrebu za intervencijama i aktivnijom ulogom civilnog društva i progresivnim politikama u ovim procesima. 


\section{Platforme kao posrednici (mrežnog) obrazovanja}

Implementacija platformi u oblasti obrazovanja nije izoliran trend, nego dio širih procesa ekonomizacije, komodifikacije i instrumentalizacije znanja u postindustrijskom društvu (Delić 2017). Iz perspektive studija znanosti i tehnologije (Law 2017), moglo bi se reći kako je uspostavljanje, održavanje i promoviranje obrazovanja kao sektora tehnološke industrije (engl. edtech industry) učinak djelovanja heterogene mreže aktera. Iako zauzimaju središnju poziciju, visokotehnološke tvrtke i digitalne tehnologije nisu jedini akteri u ovom okruženju. To su također sve one državne institucije i međunarodne organizacije, koje zahtijevaju veću tržišnu orijentaciju obrazovnog sistema, školske ustanove koje zagovaraju i implementiraju nove prakse školovanja, kao i nevladine organizacije angažirane na kampanjama promicanja novih koncepata učenja. To su, isto tako, i razne tzv. think tank organizacije koje osiguravaju intelektualnu potporu novim pristupima obrazovanju, artikuliraju vizije i obećanja oblika školovanja u budućnosti, nude dokaze o potrebama i opravdanosti tehnološki posredovane edukacije, itd. Ovdje se usmjeravamo na jedan aspekt ove dinamike: učinak platformi kao posrednika u procesu učenja i podučavanja, posebno u kontekstu (pre)vrednovanja ideje obrazovanja kao općeg dobra.

Platforme se konvencionalno razumijevaju kao online servisi koji osiguravaju prostor za pohranu i isporuku korisnički generiranog sadržaja (Rogers 2019: 153). Analize upotrebe termina od strane visokotehnoloških tvrtki i samih korisnika (Gillespie 2010) upozoravaju, međutim, na višestruka značenja izraza. U tehničkom smislu, termin upućuje na svojevrsnu softversku infrastrukturu na osnovu koje se razvija ekosistem drugih produkata. U širem, društvenopolitičkom kontekstu, izraz konotira stanovitu performativnu infrastrukturu, koja omogućava korisnicima da izraze svoje stavove i osobnosti, izgrade zajednice, ali se i povežu s oglašivačima. Višestrukost značenja posljedica je, prema Gillespie, osobitog diskurzivnog rada aktera koji nastoje, promicanjem određenih značenja, (samo)predstaviti usluge koje nude kao neutralne entitete koji povezuju korisnike. Studije (Napoli 2019; Gillespie 2018; Helmond 2015), međutim, tvrde da su platforme aktivni činioci koji uvjetuju procese u kojima sudjeluju kao posrednici. U skladu s prijedlogom teoretičarke Van Dijck (2013), platforme stoga konceptualiziramo kao socio-tehnološke konstrukte i socio-ekonomske 
strukture: programirana tehnološka ustrojstva koja organiziraju odnose između korisnika u skladu s određenim vrijednostima i interesima.

U kontekstu posredovanja obrazovanja, istraživači (Van Dijck, Poell i De Waal 2018: 120-123) upućuju na najmanje tri mehanizma koji usmjeravaju procese u "platformskom ekosistemu“ i potiču restrukturiranja postojećih praksi učenja i podučavanja: operacije datafikacije, personalizacije i komodifikacije.

Datafikacija upućuje na sposobnost mrežnih medija da prevedu različite aspekte života u trenutačno dostupne, pristupačne i pretražive podatke. Naime, platforme su u stanju posredovati razne vrste interakcija pod uvjetom da su prethodno izražene kao kvantificirajući entiteti: kodirani kao mjerljivi podaci koji se dalje mogu analizirati koristeći algoritamske procedure. Tako se svaki oblik aktivnosti posredovan pomoću platformi može prevesti i sačuvati u formi podatka. $\mathrm{Na}$ početku, ovi su se podaci tretirali kao nusprodukti upotrebe mrežnih medija prije nego što se uvidio njihov potencijal u svrhe modeliranja i predikcije ponašanja (Zuboff 2019). Operacije datafikacije ciljano su dizajnirane, samom inženjerskom izvedbom, kao nepristupačni i teško uočljivi procesi za većinu korisnika. Isti su mehanizmi automatskog generiranja i prikupljanja podataka operativni i prilikom korištenja uređaja i usluga povezanih s edukacijskim platformama. Prikupljanje podataka o obrazovnim aktivnostima učenika, nastavnika, ali i samih školskih administracija putem tehnologija praćenja podataka u realnom vremenu pruža osnovu za uvođenje i legitimiziranje kvantitativne analitike učenja kao povlaštenog (informatičkog) znanja pomoću kojeg se vrednuje i usmjerava pedagoška praksa (Pierlejewski 2020; Thoutenhoofd 2018; Roberts-Homes 2014). Pojedini autori (Stevenson 2017) smatraju da operacije datafikacije vode sve većem saobražavanju obrazovnog procesa logici brojeva, što omogućava primjenu ne samo raznih standardiziranih obrazaca mjerenja performansi nego i sistema odgovornosti povezanih s nagradivanjem i sankcioniranjem dostignute razine produktivnosti. Nerijetko se u javnim diskursima pretpostavljene prednosti takvih pristupa u unapređenju učenja predstavljaju kao već empirijski potvrđena dostignuća iako rasprave među znanstvenicima (npr. Selwyn i Gašević 2020) upućuju na značajne razlike u samom razumijevanju ovih procesa.

Personalizacija upućuje na sposobnost platformi da odaberu, filtriraju i prilagode, posredstvom algoritamskih operacija, sadržaje, usluge i produkte prema potrebama i interesima korisnika, a na temelju ranije prikupljenih i 
analiziranih podataka. U kontekstu obrazovnih platformi, personalizirano učenje podrazumijeva neprekidno nadgledanje performansi korisnika i kontinuiranu prilagodbu didaktičkih praksi njihovim potrebama, mogućnostima i uspjesima. U većini slučajeva vrlo je teško ustanoviti tačan način rada algoritama ne samo zato što su poslovna tajna nego i što se neprestano mijenjaju u skladu s promjenama u ekosistemu mrežnih medija i korištenju platformi među korisnicima. Istraživači (Ashman et al. 2014) upozoravaju da razumijevanje dugoročnih učinaka personalizacije učenja zahtijeva više istraživanja i uključenost šire zajednice u diskusiju o ovim pitanjima.

Komodifikacija se odnosi na procese preobražavanja online interakcija, odnosno tokova podataka u robu određene tržišne vrijednosti: prakse privatiziranja i monetiziranja korisnički generiranih sadržaja. Podaci prikupljeni posredstvom korištenja obrazovnih platformi imaju, drugim riječima, ne samo pedagošku nego i ekonomsku vrijednost. Studije (Van Dijck, Poell i De Waal 2018: 121) upućuju na ulogu velikih centara za obradu prikupljenih podataka koji posredstvom integriranih poslovnih modela i struktura upravljanja ekstraktuju tržišnu vrijednost i identificiraju potencijalno profitabilne sheme budućih djelovanja. Također, brojni radovi (Wilkinson i Wilkinson 2020; Williamson 2020; Saunders i Ramírez 2017; Werler 2015) naglašavaju vezu između procesa komodifikacije obrazovanja i neoliberalnih politika rekonstruiranja polja obrazovanja prema zahtjevima tržišsta. Veća „kompetitivnost“ školskih ustanova, postizanje „izvrsnosti“ u podučavanju, ostvarivanje „zadovoljstva“ učenika i drugi slični izrazi učestali u diskursu o reformama obrazovnog sistema upućuju na to. Potencijali učinkovitosti, pristupačnosti i priuštivosti obično se ističu kao prednosti online oblika obrazovanja, ali o tome još ne postoje, kako tvrde Van Dijck, Poell i De Waal, pouzdani dokazi utemeljeni na istraživanjima. Zaštita privatnosti, sigurnost učenika, jednakost pristupa uslugama, dostupnost tehnologija kao i implikacije na demokratske vrijednosti neka su od otvorenih pitanja procesa komodifikacije. 


\section{„Pandemijska pedagogija“}

Pojava bolesti COVID-19, odnosno uvođenje kompleksa mjera s ciljem sprječavanja širenja koronavirusa, naročito tzv. potpunih ili djelomičnih zatvaranja (engl. lockdown), uvjetovali su najmanje dva velika poremećaja u oblasti obrazovanja (Williamson i Hogan 2020). Prvi se odnosio na obustavljanje nastave u školama i uvođenje raznih oblika „online učenja“. ${ }^{3}$ Drugi je povezan s ulaskom, u svjetskim razmjerima, tzv. edtech industrije u sisteme javnog obrazovanja, uz nastojanje da se epidemiološka kriza iskoristi ne samo za ostvarivanje kratkoročnih ekonomskih probitaka nego i kao katalizator za korjenite reimaginacije praksi i sistema obrazovanja u budućnosti.

Naime, od proglašenja pandemije koronavirusa uočljiva su, tvrde Williamson i Hogan, orkestrirana djelovanja osobite mreže aktera usmjerena zagovaranju pristupa tzv. edtech industrije u rješavanju problema funkcioniranja obrazovnog sistema u uvjetima krize. Oblik obrazovanja na daljinu prilagođen vanrednom stanju (engl. emergency remote education) pandemije figurirao je kao ključni zahtjev. Njemu su lako mogle udovoljiti upravo privatne i komercijalne organizacije koje čine okosnicu ovog sektora visokotehnološke industrije jer su imale izgrađene i integrirane resurse, infrastrukturne i sektorske platforme globalnog opsega djelovanja. ${ }^{4}$ Brojne visokotehnološke tvrtke vidjele su krizu istovremeno i kao poslovnu priliku za ekspanziju tržišta, ali i situaciju u kojoj su mogle dokazati prednost, opravdanost i korisnost usluga koje nude, a time i dugoročno osnažiti poziciju, prisustvo i utjecaj unutar obrazovnog sistema i nakon okončanja pandemije. Studija Williamson i Hogan (2020: 14-47) također skreće pažnju i na utjecajne promotore rješenja tzv. edtech industrije, čija se djelovanja protežu na više sektora, javni, privatni i neprofitni, kao što su internacionalne multilateralne organizacije, poput Svjetske banke, OECD-a i UNICEF-a, filantropske organizacije, poput Inicijativa Chan Zuckerberg,

\footnotetext{
${ }^{3}$ Prema podacima UNESCO-a (2021), samo početkom aprila 2020. godine blizu 1,5 milijardi učenika diljem svijeta nije bilo u mogućnosti, zbog mjera zatvaranja, pohađati nastavu u učionicama.

${ }^{4} \mathrm{U}$ sektoru obrazovanja to su, na primjer, razne platforme za učenje na daljinu (npr. Google’s G Suite, Microsoft 365), menadžment-sistemi (npr. Moodle, Canvas, ClassDojo, EdModo), aplikacije za videokonferencije (npr. Zoom, Skype, Amazon Chime), pružatelji usluga online obrazovanja (npr. Udemy, Coursera, Khan Academy), aplikacije za instant komunikaciju (WhatsApp, Google Hangouts) i niz drugih usluga. Pored platformi i s njima povezanih alatki, velike korporacije kao što su Microsoft, Google i Apple poznati su kao dugogodišnji investitori u proizvode i usluge vezane za obrazovanje (laptopi, tableti i pametne table, uredski paketi, pretraživači naučnih radova, referencijalni sistemi, itd.).
} 
Gates fondacija i Google.org, think tank organizacije, itd. Komercijalni pružatelji usluga obrazovanja i organizacije koje zagovaraju njihove usluge uspostavili su, tvrde autori, moćne međunarodne koalicije, javno-privatna partnerstva i druge interesne mreže $s$ ciljem promocije, popularizacije i legitimizacije novih pristupa učenju zasnovanih na platformskoj infrastrukturi kao svojevrsnih prototipa

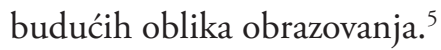

Istraživači u tom smislu pišu o „pandemijskoj pedagogiji“ (Williamson, Eynon i Potter 2020; Schwartzman 2020; Ladson-Billings 2021), osobitom pristupu obrazovanja koji se afirmirao u kontekstu vanrednog stanja povezanog s pojavom bolesti COVID-19, a čiji su oslonac platforme. Oblici učenja koji se tako realiziraju, uz posredovanje digitalnih medija, pretpostavljaju rekonfiguraciju praksi i institucija obrazovanja u skladu s normama koje privilegira samo ustrojstvo ekosistema. Iako je cjelovito mapiranje preobražaja koje uvjetuje implementacija digitalnih platformi u polju obrazovanja zadatak koje kritičke studije tek trebaju poduzeti, moguće je izdvojiti neke od indikativnih procesa. Ovisnost javnog sistema obrazovanja o privatnoj infrastrukturi globalnih visokotehnoloških korporacija, datafikacija i komodifikacija procesa učenja i podučavanja, privilegiranje pristupa informatičkih znanosti u pedagoškoj praksi, odsustvo odgovornosti i kontrole svih aktera koji su uključeni u obrazovni rad, izmještanje odlučivanja iz kruga odgajatelja, nastavnika i zajednica ka komercijalnim organizacijama, intenziviranje procesa privatizacije i komercijalizacije obrazovanja, promjena prostornih, vremenskih i porodičnih odnosa uslijed relociranja učionice u kućno okruženje, novi oblici digitalnih nejednakosti - samo su neki od nagovještaja dinamike restrukturiranja polja obrazovanja koje je ubrzala pandemija koronavirusa.

\footnotetext{
${ }^{5}$ Neki od primjera ovih koalicija su Partnerstvo globalnog obrazovanja (engl. Global Partnership for Education), Obrazovanje ne može čekati (engl. Education Cannot Wait), Fond za procjenu strateškog utjecaja (engl. Strategic Impact Evaluation Fund), Globalna koalicija za obrazovanje (engl. Global Education Coalition), Alijansa COVID-obrazovanja (engl. COVIDEducation Alliance), projekt Wide Open School, itd.
} 


\section{Zaključak: problemi skrivene i otvorene infrastrukture}

Kritičke refleksije učinaka platformi kao posrednika u procesima učenja naravno ne osporavaju važnost digitalnih medija kao obrazovnih tehnologija, nego upućuju na problematične aspekte njihovih konfiguracija.

Iako imaju svoje specifičnosti, sporna pitanja u oblasti obrazovanja treba dovesti u vezu sa središnjim temama kritičkih studija mrežnih medija. Lovink (2018) insistira na usmjeravanju pažnje ka pitanjima mrežne arhitekture i kodiranja društvenih interakcija. Rad i obilježja programiranih tehnoloških ustrojstava moraju se, tvrdi Lovink, učiniti javnim, a nevidljiva infrastruktura politizirati. Stoga je neophodno, prema mišljenju ovog autora, nastaviti pronalaziti modalitete realizacije interneta kao istinske javne infrastrukture, okruženja koje će biti u stanju odbraniti se od korporativne prevlasti i državne kontrole. Žižek (2013) u komentaru o tzv. „računarstvu u oblaku“ kao ključni problem vidi, isto tako, korporativno ustrojstvo online platformi na načelu „javne upotrebe“ $\mathrm{i}$ „privatne kontrole“: intencionalne skrivenosti mehanizama koji nadziru funkcioniranje uređaja i usluga od samih korisnika, odnosno normi i interesa koji prožimaju dizajn tehnologije. Gillespie (2010) također kritizira preovlađujući diskurs koji uz platforme vezuje vrijednosti neutralnosti i progresivne otvorenosti, istovremeno otežavajući uvide o stvarnim i suštinskim intervencijama koje platforme svakodnevno poduzimaju prilikom posredovanja društvenih aktivnosti.

S druge strane, važno je kritički razmotriti, kako što upozoravaju Van Dijck, Poell i De Waal (2018), i „alternativne“ inicijative u oblasti obrazovanja koje dolaze od, takoreći, netržišnih aktera, poput organizacija civilnog društva i vladinih institucija, usmjerene promicanju principa kombiniranog učenja (engl. blended learning) i otvorenih platformi. Kombiniranje učenja na daljinu i rada u učionicama može poboljšati, smatraju zagovornici ovih oblika nastave, proces učenja, kao i izgradnja platformi s otvorenim pristupom podacima i repozitorijima sadržaja. Ne umanjujući prednosti takvih inicijativa, važno je primijetiti kako su empirijski dokazi o učinkovitosti takvih praksi i daje oskudni i diskutabilni. Naime, otvorene platforme karakterizira ograničena održivost, visoki troškovi i nepoznati učinci u smislu osnaživanja demokratskih procesa. Načiniti podatke, znanja i vještine otvorenim nije nužan garant, tvrde Van Dijck, Poell i De Waal, 
očuvanja obrazovanja kao općeg dobra. Koncept „otvorenog“ ne mora biti, drugim riječima, istoznačan konceptu „općeg“ ili „slobodnog“.

Neosporno je da razumijevanje i regulacija procesa implementacije platformi u oblasti obrazovanja zahtijeva punu uključenost profesionalnih zajednica odgajatelja, obrazovnih institucija, roditelja i studenata, akademske zajednice, organizacija civilnog sektora, ali i same države koja mora garantirati demokratske i emancipatorske vrijednosti obrazovanja, zaštititi interese učenika, omogućiti dostupnost i pristupačnost obrazovanja kao i sisteme odgovornosti svih aktera uključenih u obrazovni proces. Racionalna, argumentirana i kritička rasprava svih aktera povezanih s obrazovanjem, dostupna javnosti, trebala bi prethoditi i kontinuirano pratiti upotrebu online platformi u svrhe obrazovanja kako bi se posredstvom suočavanja višestrukih perspektiva sagledali ne samo potencijali nego i problematični aspekti algoritamski posredovanih praksi učenja. Zahtjevi za transparentnošću mehanizama u osnovi rada platformi, kao i interesa komercijalnih organizacija zaslužnih za njihov razvoj, trebali bi biti prepoznati kao stvari od općeg dobra. Osim projekata koji imaju za cilj poboljšanje vještina korištenja platformi, angažmani stručnih udruga, organizacija civilnog društva i institucija političkog sistema moraju također biti usmjereni kritičkoj revalorizaciji ovih procesa, samom repolitiziranju naizgled depolitizirane tehnološke infrastrukture i njenom razvoju u skladu $s$ emancipatornim vrijednostima. Izostanak takvih aktivnosti samo će pospješiti trendove izmještanja procesa odlučivanja izvan institucija sistema, otežati sudjelovanje struke i javnosti te umanjiti, ako ne već i isključiti, mogućnost oblikovanja platformi na načelima primjerenim demokratskim uređenjima. 


\title{
School in the Cloud: Online Platforms as Mediators of Education
}

\begin{abstract}
The paper discusses the processes of implementation of digital platforms, a special group of network media, in the field of education. The effects of platform mechanisms on established learning concepts, especially the notion of education as a common good, are critically considered. Special attention is given to the implications of "pandemic pedagogy" conditioned by the appearance of the disease COVID-19 on the reconfiguration of previous practices and educational institutions. The paper points to the fruitfulness of the interdisciplinary dialogue of media studies and sociology of education in the analysis of the dynamics and transformation of modern educational systems.
\end{abstract}

Key words: platforms; digital media; education; edtech industry; COVID-19.

\section{Literatura}

Ashman, H. et al. 2014. The Ethical and Social Implications of Personalization Technologies for e-Learning. Information and Management, 51 (6), str. 819-32.

Bauman, Z. et al. 2014. After Snowden: Rethinking the Impact of Surveillance. International Political Sociology, 8 (2), str. 121-144.

Delić, Z. 2017. Epistemology and Transformation of Knowledge in Global Age. Rijeka: IntechOpen.

Galloway, S. 2018. The Four: the Hidden DNA of Amazon, Apple, Facebook, and Google. New York: Penguin.

Gehl, R. W. 2013. What's on your mind? Social Media Monopolies and Noopower. First Monday [online], 18 (3), doi: 10.5210/fm.v18i3.4618. [datum pristupa: 4. 4. 2021.].

Gillespie, T. 2010. The Politics of "Platforms". New Media \& Society, 12 (3), str. 347-364.

Gillespie, T. 2018. Custodians of the Internet: Platforms, Content Moderation, and the Hidden Decisions That Shape Social Media. New Heaven-London: Yale University Press.

Helmond, Anne 2015. The Platformization of the Web: Making Web Data Platform Ready. Social Media + Society [online], doi: 10.1177/2056305115603080. [datum pristupa: 4. 4. 2021.]. 
Koedinger, K.R; McLaughlin, E. M.; Stamper, J. C. 2014. MOOCs and Technology to Advance Learning and Learning Research: Data-Driven Learner Modeling to Understand and Improve Online Learning. Ubiquity, 3, str. 1-13.

Ladson-Billings, G. 2021. I'm Here for the Hard Re-Set: Post Pandemic Pedagogy to Preserve Our Culture. Equity \& Excellence in Education, 54 (1), str. 68-78.

Law, J. 2017. STS as Method. U: Felt, U., Fouché, R., Miller, C. A., Smith-Doerr, L. ur.. The Handbook of Science and Technology Studies. Cambridge, MA: The MIT Press.

Lovink, G. 2018. Social Media Abyss: Critical Internet Cultures and the Force of Negation. Malden, MA: Polity.

Napoli, P. M. 2019. Social Media and the Public Interest: Media Regulation in the Disinformation Age. New York: Columbia University Press.

Pierlejewski, M. 2020. The Data-doppelganger and the Cyborg-self: Theorising the Datafication of Education. Pedagogy, Culture \& Society, 28 (3), str. 463-475.

Roberts-Holmes, G. 2015. The 'Datafication' of Early Years Pedagogy: 'If the Teaching Is Good, the Data Should Be Good and if There's Bad Teaching, There Is Bad Data'. Journal of Education Policy, 30 (3), str. 302-315.

Rogers, R. 2019. Doing Digital Methods. London-Thousand Oaks: SAGE Publications.

Rupčić, D. 2015. Humanističko obrazovanje kao posljednja svrha ljudskog opstanka. Metodički ogledi, 22 (2), str. 95-115.

Saunders, D. B.; Ramírez, G. B. 2017. Against „Teaching Excellence“: Ideology, Commodification, and Enabling the Neoliberalization of Postsecondary Education. Teaching in Higher Education, 22 (4), str. 396-407.

Schwartzman, R. 2020. Performing Pandemic Pedagogy. Communication Education, 69 (4), str. 502-517.

Selwyn, N.; Gašević, D. 2020. „The Datafication of Higher Education: Discussing the Promises and Problems“. Teaching in Higher Education, 25 (4), str. 527-540.

Selwyn, N.; Henderson, M.; Chao, S. 2016. The Possibilities and Limitations of Applying "Open Data" Principles in Schools. Cambridge Journal of Education, 47 (2), str. 167-87.

Stevenson, H. 2017. The „Datafication“ of Teaching: Can Teachers Speak Back to the Numbers?. Peabody Journal of Education, 92 (4), str. 537-557.

Thoutenhoofd, E. D. 2018. The Datafication of Learning: Data Technologies as Reflection Issue in the System of Education. Studies in Philosophy and Education, 37, str. 433-449.

UNESCO. 2021. Covid-19 Impact on Education [online], UNESCO. Dostupno na: https://en.unesco.org/covid19/educationresponse [datum pristupa: 4. 4. 2021.].

Van Dijck, J. 2013. The Culture of Connectivity: a Critical History of Social Media. Oxford: Oxford University Press. 
Van Dijck, J.; Poell, T. 2015. Higher Education in a Networked World: European Responses to American MOOCs. International Journal of Communication, 9, str. 2674-92.

Van Dijck, J., Poell, T., Waal, M. 2018. The Platform Society: Public Values in a Connective World. New York: Oxford University Press.

Werler, T. (2015). Commodification of Teacher Professionalism. Policy Futures in Education, 14 (1) , str. 60-76.

Wilkinson, L. C. \& Wilkinson, M. D. 2020. Value for Money and the Commodification of Higher Education: Front-line Narratives, Teaching in Higher Education [online], doi: 10.1080/13562517.2020.1819226.

Williamson, B.; Hogan, A. 2020. Commercialisation and Privatisation in/of Education in the Context of Covid-19. Brussels: Education International.

Williamson, B. 2017. Who Owns Educational Theory? Big Data, Algorithms and the Expert Power of Education Data Science. E-Learning and Digital Media, 14 (3), str. 105-122.

Williamson, B. 2020. Making Markets Through Digital Platforms: Pearson, Edubusiness, and the (E)valuation of Higher Education. Critical Studies in Education, 61 (1), str. 50-66.

Williamson, B.; Eynon, R.; Potter, J. 2020. Pandemic Politics, Pedagogies and Practices: Digital Technologies and Distance Education During the Coronavirus Emergency. Learning, Media and Technology, 45 (2), str. 107-114.

Yeung, K. 2018. Five Fears About Mass Predictive Personalisation in an Age of Surveillance Capitalism. International Data Privacy Law, 8 (3), str. 258-269.

Zuboff, S. 2019. The Age of Surveillance Capitalism: the Fight for a Human Future at the New Frontier of Power. London: Profile Books.

Žižek, S. 2013. Sloboda u oblaku. Peščanik, [online]. 21.8.2013. Dostupno na: www. pescanik.net/sloboda-u-oblaku/ [datum pristupa: 4. 4. 2021.]. 